\title{
Feeding of two sympatric species of Characidium, C. lanei and $C$. pterostictum (Characidiinae) in a coastal stream of Atlantic Forest (Southern Brazil)
}

\author{
José Marcelo R. Aranha ${ }^{1,2 *}$, José Henrique C. Gomes ${ }^{2}$, Fábio N. O. Fogaça1 \\ ${ }^{1}$ Depto de Zoologia, SCB, Universidade Federal do Paraná, CP 19020, CEP 81531-990, Curitiba - PR, Brazil; \\ ${ }^{2}$ Programa de Pós-graduação em Ecologia e Recursos Naturais, Depto de Hidrobiologia, Universidade Federal de \\ São Carlos, CP 676, CEP 13565-905, São Carlos - SP, Brazil
}

\begin{abstract}
The feeding strategy of Characidium lanei and C. pterostictumwas studied in the "Cabral" stream, a coastal stream of the Atlantic Forest, in southern Brazil. The samples were taken using electric fishing between March/95 and February/96. We studied about 15 stomach contents for each species in each season of the year. The stomach contents of the studied species were composed of 39 different food items, 28 in C. lanei and 24 in C. pterostictum Chironomidae larvae and Ephemeroptera nymph were the most important items for $\mathrm{C}$. lanei, except in the summer when Acarina and not identified Arthropoda were the most important items. Chironomidae and Simulidae larvae were the most important items in $\mathrm{C}$. pterostictum These results indicated an insectivorous habits and opportunist feeding strategy to C. lanei and C. pterostictum with several items rare or not very frequent.
\end{abstract}

Key words: feeding, sympatric species, Atlantic Forest, Coastal Stream, Characidiinae, Characidium

\section{INTRODUCTION}

Feeding is one of the most important biological factors and its abundance and variety influence the structure and composition of fish populations.

Freshwater fishes present several feeding specialisations, but the majority exhibits considerable feeding plasticity (Larkin, 1956; Lowe-McConnell, 1987 and Gerking, 1994), which favours the use of items seasonally abundant, mainly in habitats with great environmental instability. Knowledge of diet, feeding strategy and trophic relationships among fish species are fundamental for the understanding of the structure and dynamics of those communities.

The coastal streams are unstable ambients, rich in independent evolutionary histories and endemisms (Böhlke et al., 1978 and Castro \& Casatti, 1997). This heterogeneity makes the study of bionomic strategies excellent models to understand adaptative mechanisms. However, these habitats are exposed to the increasing anthropogenic pressure, despite their importance for the biodiversity preservation and for the human health (natural water resources). The Atlantic Forest is one of the most threatened Brazilian ecosystems, making these studies urgent and so necessary for the environmental management.

This paper aims to analyse and compare the feeding of two species of Characidiinae, Characidium lanei Travassos, 1967 and $C$. pterostictum Gomes, 1947, in a coastal stream (the "Cabral" stream, Antonina, PR-Brazil), verifying possible variations along one year.

\section{MATERIALS AND METHODS}

We collected Characidum lanei and $C$. pterostictum, between March/95 and February/96, using electric fishing in the mid-stream of the

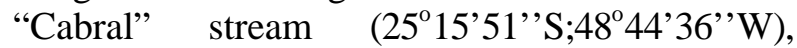
which is a second order river with very clear water in the municipality of Antonina (State Paraná,

\footnotetext{
* Author for correspondence
} 
Brazil). In the studied area the riparian vegetation is composed of trees and shrubs on the right edge and herbaceous plants on the left one. The average depth is $50 \mathrm{~cm}$, and the average distance between the banks is aproximately 3 to $4 \mathrm{~m}$. The substrate is composed of areas with sand and pebbles and riffles with stones and rocks.

We studied 15 stomach contents by chance for each species in each season of the year. The diet was analysed according to the frequency of occurrence $(\% \mathrm{O})$ and points (\%P) methods (Hyslop, 1980). The number of points of each item was attributed by the volumetric proportion of the item in the stomach contents according to scale in Table 1 . The feeding index (IAi according to Kawakami \& Vazzoler, 1980) was calculated to obtain the relative importance of each food item, using the results of the frequency of occurrence and the volume percentage:

$$
\mathrm{IAi}=\left(\% \mathrm{O}_{\mathrm{i}} \times \% \mathrm{~V}_{\mathrm{i}}\right) / \Sigma{ }_{\mathrm{i}=1}^{\mathrm{n}}\left(\% \mathrm{O}_{\mathrm{i}} \times \% \mathrm{P}_{\mathrm{i}}\right)
$$

The evenness index (here called EI; Pielou, 1977 in Ludwig \& Reynolds, 1988) was calculated for each season to obtain the heterogeneity in diets during the year. So, if the abundance of the most important items was higher, the EI should be lower and vice versa.

Table 1- Attributed points for each volumetric proportion of the item in the stomach contents of $C$. lanei and $C$. pterostictum in the "Cabral stream".

\begin{tabular}{c|c}
\hline Volume of the item & Number of Points \\
\hline$<5 \%$ & 0.5 \\
\hline $5.1-15 \%$ & 1 \\
\hline $15.1-25 \%$ & 2 \\
\hline $25.1-35 \%$ & 3 \\
\hline $35.1-45 \%$ & 4 \\
\hline $45.1-55 \%$ & 5 \\
\hline $55.1-65 \%$ & 6 \\
\hline $65.1-75 \%$ & 7 \\
\hline $75.1-85 \%$ & 8 \\
\hline $85.1-95 \%$ & 9 \\
\hline$>95$ & 10 \\
\hline
\end{tabular}

\section{RESULTS}

We examined 123 stomach contents, 63 of $C$. lanei (2.5-5.3 total length) and 60 of C. pterostictum (2.5-7.1 TL). The stomach contents of the studied species were composed of 39 different food items,
28 in C. lanei and 24 in C. pterostictum (Table 2). Several items were rare and we grouped them in 19 categories (Table 3 ).

Table 2 - Diet itens of $C$. lanei and C. pterostictum in the "Cabral stream". (symbol: symbols of group of items used in the Fig 1 and 2; A: autumn; W: winter; Sp: spring; Su: summer; $L=$ larvae; $N=$ nymph; $A=$ adult; $\mathrm{n} / \mathrm{i}=$ not identified)

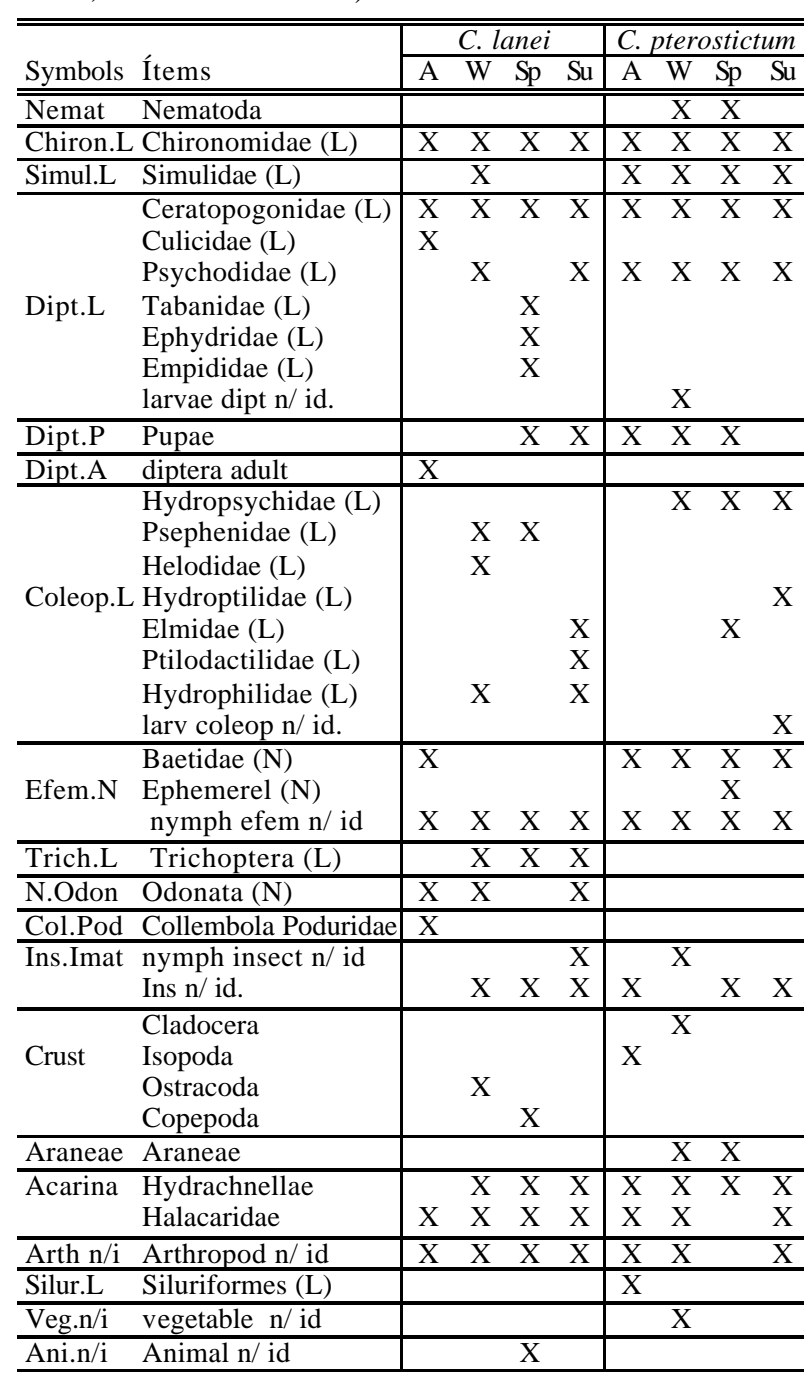

Both species ate predominantly insects. Chironomidae larvae and Ephemeroptera nymph were the most important items for $C$. lanei, except in the summer when Acarina and not identified Arthropod were the most important items (fig. 1). For this species, Simulidae larvae was rare; and Trichoptera larvae and Odonata nymph were frequent but occurred in small volumetric proportion.

Chironomidae and Simulidae larvae were the most important items in C. pterostictum (fig. 2). Ephemeroptera nymph and not identified 
Arthropods were frequent in C. pterostictum but the IAi of these items was much lower than in the C. lanei.

Table 3 - Feeding index (IAi) to stomach contents of the C. lane $i$ and $C$. pterostictum in the "Cabral" stream. $(\mathrm{A}=$ adults; $\mathrm{L}=$ larvae; $\mathrm{N}=$ nymphs; and $\mathrm{n} / \mathrm{i}=$ not identified)

\begin{tabular}{lcccccccc}
\hline & \multicolumn{1}{c}{ Aut } & \multicolumn{9}{c}{ Win } & \multicolumn{2}{c}{ (95 } & \multicolumn{3}{c}{ Spr $/ 95$} & \multicolumn{2}{c}{ Sum $/ 96$} \\
Items & $\mathrm{Cl}$ & $\mathrm{Cp}$ & $\mathrm{Cl}$ & $\mathrm{Cp}$ & $\mathrm{Cl}$ & $\mathrm{Cp}$ & $\mathrm{Cl}$ & $\mathrm{Cp}$ \\
\hline Nematoda & - & - & - & 1,4 & - & 1,0 & - & - \\
Chironomidae (L) & 34,3 & 48,3 & 26,3 & 38,5 & 22,8 & 45,0 & 12,8 & 51,0 \\
Simulidae (L) & - & 19,8 & 2,7 & 17,2 & - & 26,8 & - & 36,5 \\
Others Diptera (L) & 5,9 & 2,7 & 6,8 & 7,1 & 9,6 & 4,1 & 2,9 & 2,8 \\
Pupae of Diptera & - & 2,4 & - & 0,7 & 1,3 & 1,0 & 1,4 & - \\
Diptera (A) & 4,7 & - & - & - & - & - & - & - \\
Coleoptera (L) & - & 2,7 & 5,5 & 8,1 & 0,7 & 3,1 & 6,6 & 1,6 \\
Efemeroptera (N) & 32,3 & 9,1 & 33,8 & 6,4 & 35,0 & 11,7 & 12,8 & 0,8 \\
Trichoptera (L) & - & - & 2,4 & - & 7,9 & - & 8,8 & - \\
Odonata (N) & 1,8 & - & 6,8 & - & - & - & 5,1 & - \\
Collembola Poduridae & 0,3 & - & - & - & - & - & - & - \\
Imature insects (n/i) & 8,3 & 1,0 & 0,7 & 3,4 & 4,6 & 4,8 & 6,6 & 0,4 \\
Crustaceae & - & 2,0 & 1,4 & 3,4 & 0,3 & - & - & - \\
Araneae & - & - & - & 0,3 & - & 0,7 & - & - \\
Acarina & 5,9 & 1,7 & 2,4 & 2,0 & 6,9 & 1,7 & 27,5 & 2,4 \\
Arthopod (n/i) & 6,5 & 3,7 & 11,3 & 9,5 & 10,6 & - & 15,4 & 4,8 \\
Siluriforme (L) & - & 6,7 & - & - & - & - & - & - \\
Vegetable (n/i) & - & - & - & 2,0 & - & - & - & - \\
Animal (n/i) & - & - & - & - & 0,3 & - & - & - \\
\hline
\end{tabular}

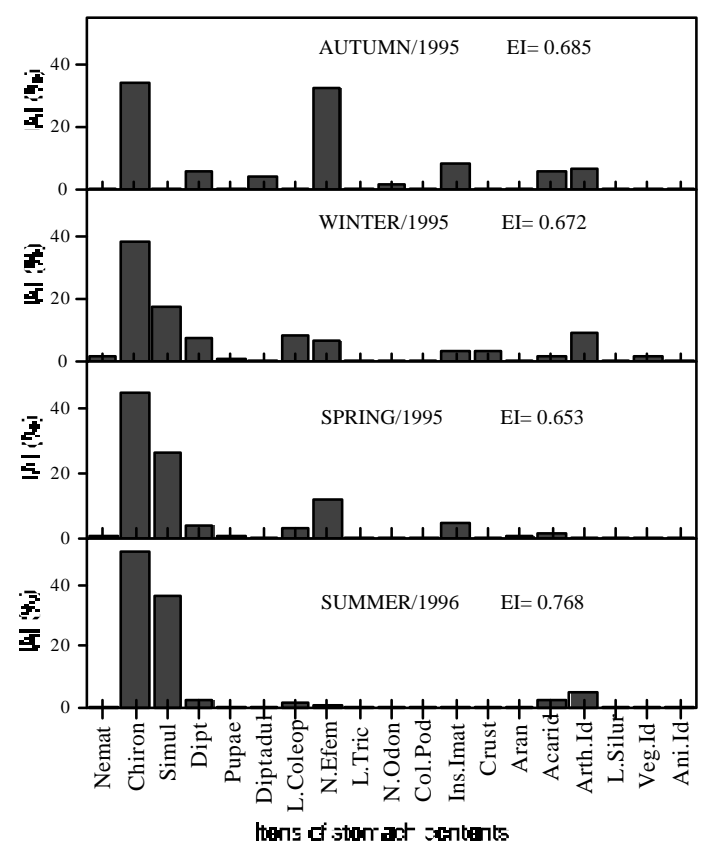

Figure 1 - Diet of $C$. lane $i$ in the "Cabral" stream. The symbols of the items were in the Table 2. (EI= evenness index).

The EI values were higher in $C$. lanei (fig. 1) and lower in C. pterostictum (fig. 2) in summer.

\section{DISCUSSION}

The Characidiinae is a fish group of small size species that inhabits preferably stony river beds in rapids (Saul, 1975; Costa, 1987 and Sabino \& Castro, 1990). Aranha et al. (1998) verified that Characidium lanei and C. pterostictum in the "Mergulhão" stream occupied "the bottom in deep sites and waters with current more than $0.25 \mathrm{~m} \cdot \mathrm{s}^{-1}$ ". The body shape and the pectoral and pelvic fins, enlarged and located in the ventral position, allow these species to maintain themselves firmly attached to the substratum, resisting to the current flow.

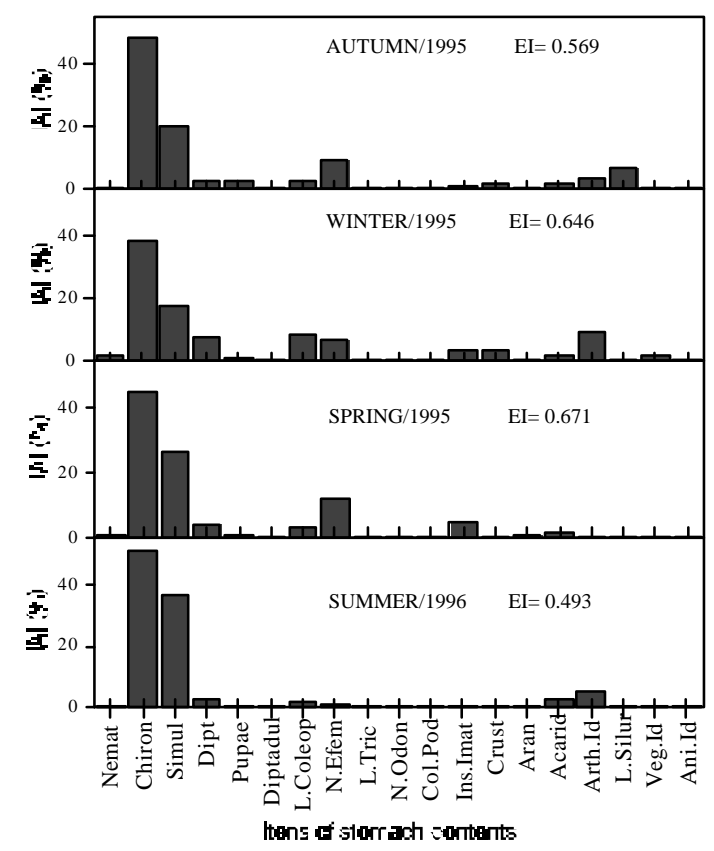

Figure 2 - Diet of C. pterostictum in the "Cabral" stream. The symbols of the items were in the Table 2. $(\mathrm{EI}=$ evenness index $)$.

These anatomical characteristics favour the food capture in places of difficult access for other fishes, like gaps among submerged stones. In the literature, the basic diet of this group is insectivore, with predominance of immature insects (Godoy, 1975; Saul, 1975; Costa, 1987, Sabino \& Castro, 1990, Castro \& Casatti, 1997 and Uieda et al., 1997).

Diets of $C$. lanei and $C$. pterostictum in the "Cabral" stream can be considered rich, with several specialisation and generalisation degrees in different items. Although the main food items were common for the two species, different values of relative importance were observed (e.g. Simuliidae larvae and Ephemeroptera nymph).

Sabino \& Castro (1990) working in another coastal stream in São Paulo State, observed two feeding tactics for Characidium sp. (C. japuhybensis, 
according to Castro \& Casatti, 1997): "sit-andwait" (sensu Sazima, 1986) and "hunting by speculation" (sensu Curio, 1976). In the first one, fish stays stationary on the bottom, capturing arrested food in short and successive leaps. In the second type, fish captures the food burying the point of the snout in the substratum, at the same time his body is obliquely inclined. The alimentary tactics of $C$. lanei and $C$. pterostictum were considered by Aranha et al. (1998) as "sit-andwait" in the "Mergulhão" stream, which is near the "Cabral" stream.

Diet of studied species changed during the year, mainly in summer. $C$. lanei's diet was more diverse during the summer in which few items with high IAi resulted in a high EI. In this season, mites and remains of arthropods (the two highest IAi) totalled 42.85. C. pterostictum's diet was more restricted to Chironomidae and Simuliidae larvae in this period, which together totalled 87.48 in IAi, resulting the lowest EI values. The "Cabral" stream is characterised by storms which cause flash floods, specially between December and February. These floods modify the structure of the river bed, causing great alterations in the fish community and in their food availability. Thus, summer is a critical season for both species and the variation in their diet at this time suggests differentiation in their feeding strategy to survive in an environment with strong natural disturbance.

\section{ACKNOWLEDGEMENTS}

We are very thanks to the friends who help us in collecting fishes. Márcia S. Menezes and Talita Aguiaro helped us with comments and suggestions for the manuscript. This project received financial support by Conselho de Desenvolvimento Científico e Tecnológico (CNPq).

\section{RESUMO}

Foi estudada a dieta de Characidium lane $i$ and $C$. pterostictum no rio Cabral, rio costeiro da Mata Atlântica na região sul do Brasil, município de Antonina - PR. As coletas foram realizadas no período de março/95 a fevereiro/96, utilizando-se de pesca elétrica. A cada estação do ano, 15 exemplares de cada espécie tiveram seus conteúdos estomacais estudados. Foi constatado para C. lanei 28 ítens e para C. pterostictum 24 ítens. Para $C$. lanei, os ítens mais importantes foram larvas de Chironomidae e de Ephemeroptera, exceto m verão quando ácaros e restos de artrópodes foram mais significativos. Para C. pterostictum os ítens larva de Chironomidade e de Simulidae predominaram durante todo o ano. Os resultados no presente estudo sugerem uma dieta oportunista dentro de insetivoria, com grande ocorrência de ítens raros ou pouco freqüentes.

\section{REFERENCES}

Aranha, J.M.R.; Takeuti, D.F. and Yoshimura, T.M. (1998), Habitat use and food partitioning of the fishes in a coastal stream of Atlantic Forest, Brazil. Rev. Biol. Trop. 46, 955-963

Böhlke, J.E.; Weitzman, S.H. and Menezes, N.A. (1978), Estado atual da sistemática dos peixes de água doce da América do Sul. Acta Am., 8, 657-677

Castro, R.M.C. and Casatti, L. (1997), The fish fauna from a small forest stream of the upper Paraná River basin, southeastern Brazil. Ichthyol. Explor. Freshwaters, 7, 337-352

Costa, W.J.E.M. (1987), Feeding habits of a fish community in a tropical coastal stream, Rio Mato Grosso, Brazil. Stud. on Neotrop. Fauna and Environ., 22, 145-153

Curio, E. (1976), The ethology of predation. SpringerVerlag, Berlin

Gerking, S.D. (1994), Feeding ecology of fishes. Academic Press, London

Godoy, M.P. (1975), Peixes do Brasil: Subordem Characoidei. Ed. Franciscana, São Paulo

Hyslop, E.J. (1980), Stomach contents analysis - a review of methods and their application. J. Fish Biol., 17, 411429

Kawakami, E. and Vazzoler G. (1980), Método gráfico e estimativa de índice alimentar aplicado no estudo de alimentação de peixes. Bolm. Inst. Oceanogr., 29, 205-207

Larkin, P.A. (1956), Interspecific competition and population control in freshwater fish. J. Fish. Res. Bd. Can., 13, 327-342

Lowe-McConnell, R.H. (1987), Ecological studies in tropical fish communities. Cambridge Univ. Press, London

Ludwig, J.A. and Reynolds J.F. (1988), Statistical ecology. A primer on methodsand computing. John Wiley and Sons, New York

Pielou, E.C. (1977). Mathematical Ecology. John Wiley and Sons, New York

Sabino, J. and Castro, R.M.C. (1990), Alimentação, período de atividade e distribuição espacial dos 
peixes de um riacho da floresta Atlântica (sudeste do Brasil), Rev. Brasil. Biol., 50, 23-26

Saul, W.G. (1975), An ecological study of fishes at a site in upper Amazonian Ecuador. Proc. Acad. Nat. Sci. Philad., 127, 93-134

Sazima, I. (1986), Similarities in feeding behaviour between some marine and freshwater fishes in two tropical communities, J. Fish Biol., 29, 53-65
Uieda, V.S., Buzzato, P. and Kikuchi, R.M. (1997), Partilha de recursos alimentares em peixes em um riacho de serra do sudeste do Brasil. An. Acad. Bras. Ci., 69, 243-252

Received: September 16, 1999; Revised: February 17, 2000; Accepted: March 13, 2000. 